\title{
Primary Cutaneous B-Cell/T-Cell (Non- MF/SS) Lymphoma T2c TNM Finding v8
}

National Cancer Institute

\section{Source}

National Cancer Institute. Primary Cutaneous B-Cell/T-Cell (Non-MFISS) Lymphoma T2C

TNM Finding v8. NCI Thesaurus. Code C141390.

All disease encompassing in a 30-cm or more circular area. (from AJCC 8th Ed.) 